\title{
PEMBUATAN HANG LEDDER SEBAGAI SARANA BERLATIH KETINGGIAN DAN PENGUATAN OTOT ANAK-ANAK DI TK DHARMA WANITA PERSATUAN 3 KALIASRI DUSUN UMBULDAWE RT01 RW 08 DESA KALIASRI , KECAMATAN KALIPARE KAB. MALANG
}

Eko Hendry Suyono, Nurchajat, Vinan Viyus, Maskuri, Subagiyo Jurusan Teknik Mesin, Politeknik Negeri Malang

\begin{abstract}
Abstrak - Salah satu bentuk pendidikan prasekolah bagi anak-anak usia dibawah 7tahun ialah play grup,serta taman kanak kanak. di desa desa dan kecamatan terdapat banyak pendidikan Taman Kanak Kanak serta play grup.. Pendidikan ini pada umumnya dikelola swasembada, karena pemerintah belum banyak menyediakan bantuan pendidikan Taman Kanak Kanak khususnya di tingkat desa . sehingga kebanyakan Taman Kanak Kanak di daerah pedesaan itu swakelola. Kecamatan Kalipare terletak $45 \mathrm{Km}$ kearah selatan kota Malang, dan Di Desa. Kaliasri masih belum banyak TK karena untuk mendirikan TK maupun playgrup banyak persyaratan yang harus dipenuhi : guru yang kompeten dibidangnya, gedung sekolah, ruang bermain, sarana bermain dan fasilitas lain yang mendukung proses belajar mengajar. itu semua memerlukan dana yang cukup besar. Dengan jumlah fasilitas bermain yang masih minim TK Dharma Wanita Persatuan 3 Kaliasri.terus meningkatkan pelayanan pendidikan prasekolah kepada masyarakat sekitarnya. Dalam operasional sehari-harinya dana yang diperoleh dari masyarakat sangat kurang, sehingga untuk pelaksanaan harian dan pengembangan sarana penunjang untuk bermain bagi anak-anak peserta didik tentu saja tidak mungkin. Oleh karena itu dengan adanaya pengapdian masyarakat ini maka sekolah merasa sangat terbantu dengan ditambahnya sarana bermain "Hang ledder".
\end{abstract}

Kata kunci: Hang ladder, berlatih, ketinggian

\section{PENDAHULUAN}

\subsection{Latar Belakang}

Salah satu bentuk pendidikan bagi anak-anak di tingkat kecamatan adalah pendidikan Taman Kanak Kanak. Pendidikan ini pada umumnya dikelola oleh swasta, karena pemerintah belum banyak menyediakan sarana pendidikan Taman Kanak Kanak khususnya di tingkat kecamatan ataupun pedesaan. sehingga kebanyakan Taman Kanak Kanak di kecamatan maupun tingkat pedesaan itu swakelola.

Kecamatan Kalipare terletak $45 \mathrm{Km}$ kearah selatan kota Malang, dan Di Kec. Kalipare masih belum banyak TK karena untuk mendirikan TK banyak persyaratan yang harus dipenuhi : guru yang kompeten dibidangnya, ruang bermain, sarana bermain dan fasilitas lain yang mendukung proses belajar mengajar.itu semua memerlukan dana yang cukup besar. Dengan jumlah fasilitas bermain yang masih minim TK dharma persatuan 3. Pengelolaan TK ditangani secara swakelola, namun dalam pelaksanaan sehari-harinya diketahui bahwa dana yang tersedia yang diperoleh dari masyarakat sangat minim, sehingga untuk pelaksanaan harian apalagi pengembangan sarana penunjang untuk bermain bagi anak-anak peserta didik tentu saja sangat kurang. Oleh karena itu melalui dana pengabdian masyarakat digunakan untuk mengembangkan dan mewujudkan satu sarana penunjang berupa "hang ledder".

\subsection{Manfaat kegiatan}

Manfaat yang dapat diperoleh dari kegiatan pengabdian kepada masyarakat ini adalah:

1) Mempercepat proses pemeratan pendidikan

2) Meringankan beban masyarakat dalam bidang pendidikan.

3) Menunjang program pemerintah dalam wajib belajar.

\section{BAHAN DAN PERALATAN}

\subsection{Bahan}

Untuk membuat tangga kubus ini diperlukan diantaranya :

Bahan:

- Pipa galvanis $\varnothing 35 \mathrm{~mm}$ sebanyak 12 linjor.

- Cat besi $4 \mathrm{~kg}, 4$ warna

- Cat dasar $2 \mathrm{~kg}$

- Tinner A 10 liter.

- Kertas gosok 5lbr

- Spray gun. 1bh

- Kwuas 2.5" 5bh

- Elektroda Ø2,6 mm $1 \mathrm{~kg}$.

- Semen 1sak

- Batu gerinda tangan 2bh.

- Batu gerinda potong $1 \mathrm{bh}$.

\subsection{Mesin}

- Mesin las SMAW 1bh.

- Gerinda potong ibh.

- Gerinda tangan 1bh

\section{PELAKSANAAN}

- Pembuatan hang ledder dengan proses memotong pipa galvanis sesuai gambar.

- Tack weld sesuai gambar.

- Pengelasan

- Pembersihan dengan kertas gosok

- Pengecatan dasar

- Pengecatan sesuai warna warni.

- Pemasangan dilokasi.

\subsection{Dokumentasi}




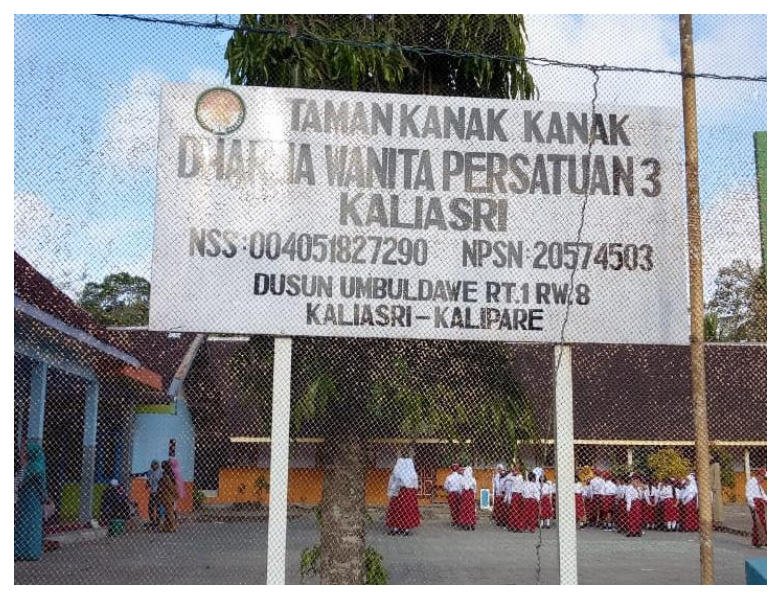

Gambar 1. Lokasi PkM
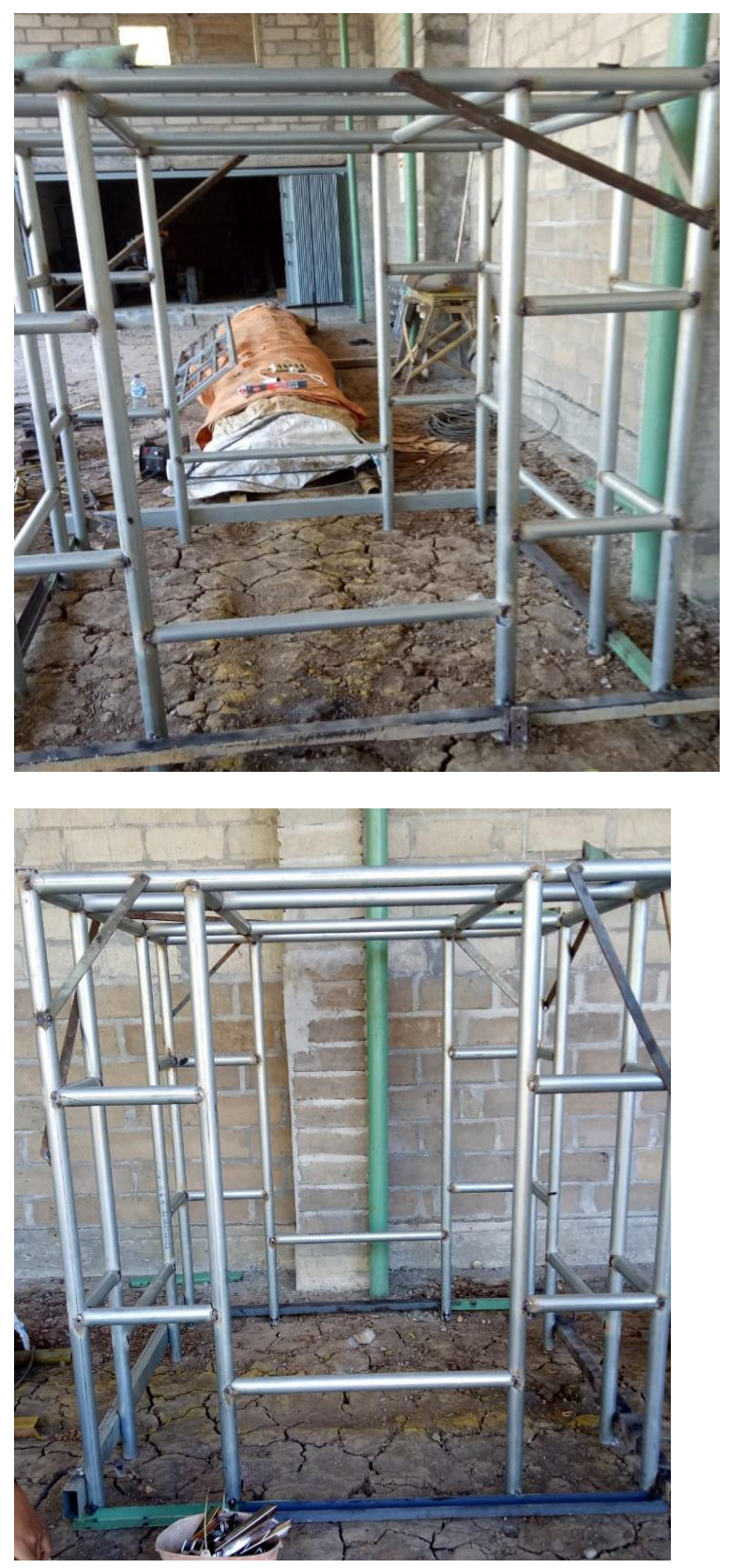

Gambar 2. Tack weld

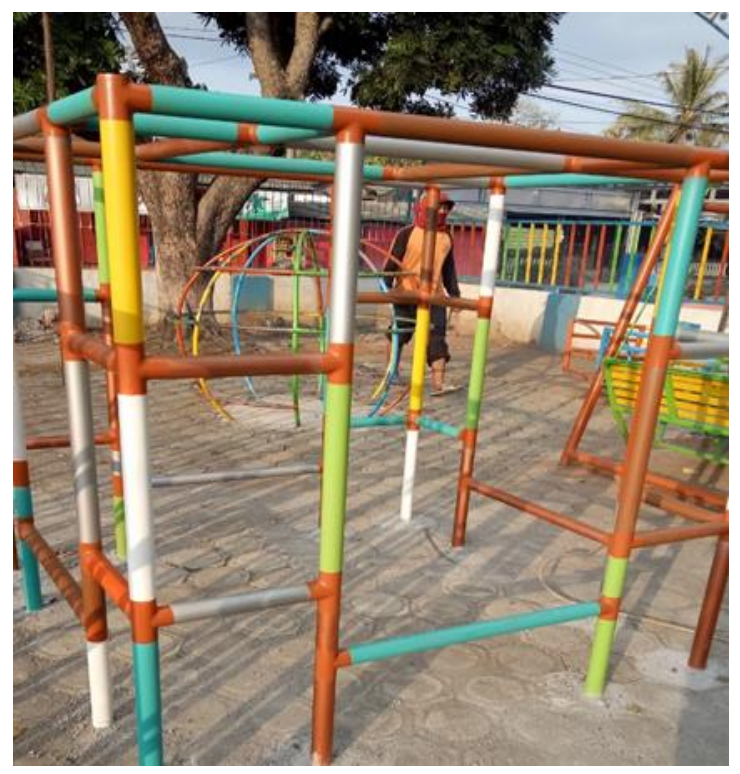

Gambar 3. Pemasangan Hang ledder

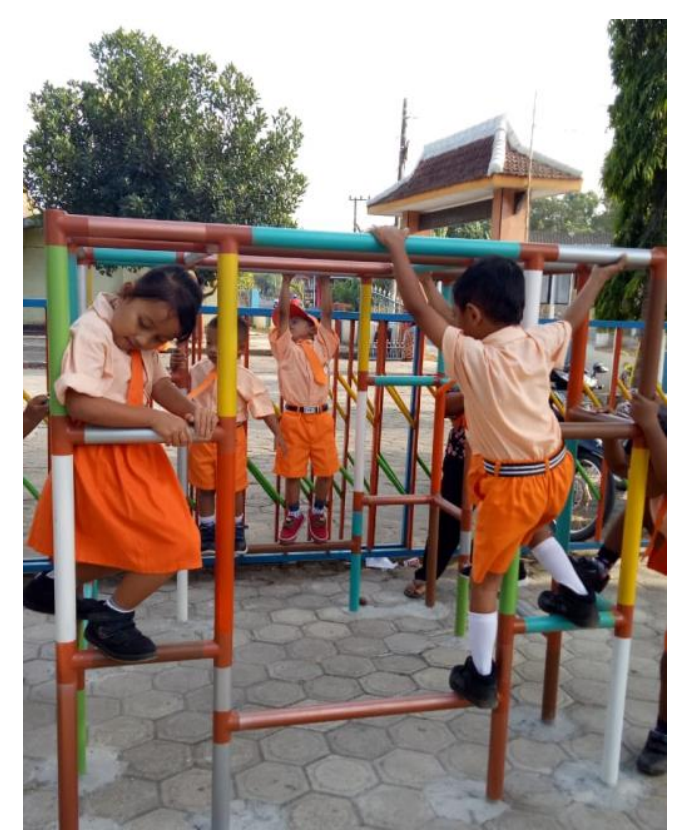

Gambar 3. Siswa TK

\section{KESIMPULAN DAN SARAN}

\subsection{Kesimpulan}

Pelaksanaan pengabdian masyarakat sesuai jadwal yang telah ditetapkan yaitu mulai tgl 1 April 2019 sampai dengan 31 Oktober 2019.

\subsection{Saran}

Perlu adanya kegiatan PKM lain sejenis untuk menambah fasilitas bermain bagi anak-anak didik di TK DHARMA WANITA PERSATUAN 3 KALIASRI. Kec Kalipare Kab. Malang 


\section{DAFTAR PUSTAKA}

[1]. Anonim 2019 A. https:www//google.co.id diakses 18 Maret 2019

[2]. Anonim 2019 A https:www//google.co,id diakses 20 Nopember 2019

[3]. Paul DeGarmo. E. 1979."Materials and Processes in Manufacturing". 5ed. New York: Macmillan. P.341, 342 dan 356 